\title{
Unceratainty of Heisenberg in Universe Destruction
}

\begin{abstract}
Sri Jumini ${ }^{1}$
${ }^{1}$ Study Program of Physics Education of Quranic Science University Central Java in Wonosobo. Jl. Raya Kalibeber Km. 03 Mojotengah Wonosobo Jawa Tengah Indonesia

Email ${ }^{1}$ : umyfadhil@yahoo.com

Abstract. The Qur'an is a guidence which explaines all about the universe to human being. The discovery of science has been able to explain the truth of the Qur'an scientifically. One of which is the principle of Heisenberg's uncertainty in the event of the universe destruction. The purpose of this research is to know: 1) Science's view of the event of the universe destruction (Big Crunch) in Qur'an [Al Infithaar]: 1-3, and How the relation of Heisenberg's uncertainty principles and the law of thermodynamics II toward the collapse of the universe (Big Crunch) based on Scientific views and the Quran. This research is a qualitative research using library research method which analyzes the related books directly or indirectly. The results of the analysis stated that: 1) The concentration of mass, which is big enough, relates to some of the laws of physics, those are: Relativity, Heisenberg's uncertainty principles, and the law of Thermodynamic II; 2) The universe will return at its sole point, i.e; the absence of the universe; 3 ) The destruction of the universe is the destruction of the order of the universe which then the stars fall scatteredly because of the gravitational force that prevents them disappears, the balance of the universe diminishes, decreases and becomes uncertain, and eventually disappears.
\end{abstract}

\section{Introduction}

The destruction of the universe is the greatest event of a natural phenomenon that will inevitably occur. The destruction of the inner universe is often called the apocalypse. When this phenomenon occurs, the universe will again shrink and shrink, so the celestial bodies collide with one another by a powerful force of gravity and eventually reenter the singularity to nothing [1]. At that time all beings like humans, animals, plants, mountains, sea, sky, etc becomes chaotic [2]. The destruction of the universe, accompanied by the state of mankind means the destruction of all civilization. The event of the destruction of the universe is one of the signs of doomsday where the celestial bodies collide, some are floating like clouds, and the atmosphere is totally dark. The end of the universe coincides with the beginning of a new life in the here after [3].

The Qur'an has explained the destruction of the universe especially related to its marks, its horror and its awesomeness since 15 centuries ago. The destruction of the universe in the Qur'an is depicted in Al Infithaar/82: 1-3.

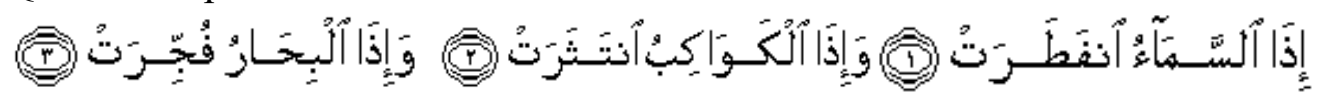

"When the heavens are split, and when the stars fall apart, and when the oceans overflow" (Al Infithaar/82:1-3) [4]. 
Based on Al Infithaar / 82: 1-3, it can be known how the destruction of the universe detailly. The second verse of this surah has its own connection with the existence of a powerful force of gravity that encourages the fall of stars scattered. While the first and third verses describe the event of the destruction of the universe generally.

The destruction of the universe makes the size of the particles in it to be atomic or sub-atomic. According to Heisenberg's uncertainty theory when nature is at the size of subatomic as evasive to be known by humans, it is not due to human incapacity or the limitation of the tool, but it is the attribute of nature to the universe [5]. The Qur'an as revelation with its absolute truth must always be reinterpreted in accordance with the needs of the present, and of science as a universal and scientifically proven knowledge. It is deemed necessary to undertake an examination of the Heisenberg Uncertainty theory and the destruction of the universe viewed from the Qur'an and Science.

\section{Methods}

The research uses qualitative approach. The type of research used is the library research, namely literature research by reviewing and analyzing books that relate directly or indirectly. Library research is a research that utilizes the library source to obtain the data. The data source used is limited only to library collection material [6]. This study conducts a series of activities related to library data collection methods, reading and taking notes and processing of research materials by collecting and reviewing various libraries namely Al Qur'an, relevant books and other scientific papers related to research purposes.

Sources of the data are divided into two: 1) primary data, data collected by the researchers from the first source or where the object of research is conducted in the form of Tafsir Al-Qur'an Al Infithaar/82: 1-3 and books related to the destruction of the universe and Heisenberg Uncertainty theories; 2) secondary data, i.e articles, magazines, journals and internet sites related to the theoretical relation Heisenberg's uncertainty with the destruction of the universe in the perspective of the Qur'an and Science. Data collection used is documentation technique. Data analysis is done by descriptive analysis method. Technical analysis is done with inductive thinking techniques and techniques of interpretation of the Qur'an with analytical techniques (tahlili). The tahlili (analytical) method is used to interpret the verses of the Qur'an by exposing all aspects of the womb in the interpreted verses and to explain the contained meanings [7].

\section{Result and Discussion}

The universe includes the micro cosmos and the macrocosm. Microcosm is things that have very small size, such as atoms, electrons, and so forth. While macro cosmos are objects that have a very large size, such as stars, planets, galaxies. The universe starts from a single point. According to the calculations, it shows that the single point containing all matter of this universe has zero volume and unlimited density. The universe is created by the explosion of a single point that has a zero volume. The great explosion that marked the beginning of the universe was called the big bang. Actually, 
this single point means nothing. The universe emerges from nothing. In other words the universe was created, not already there before.

\subsection{The destruction of the Universe}

Big bang takes place through the explosion of a point that contains all the matter and energy of the universe and its spreading to all corners of space at a very high speed. From this matter and energy, there arises an extraordinary balance that surrounds various galaxies, stars, suns, moons, and other celestial bodies [8]. Since its creation, the universe has continued to expand. The expansion of the universe means that if the universe can move backward into the past, then it is evident that the universe comes from a single point. The calculations show that this single point contains all the matter of the universe and has a zero volume, as well as an infinite density [9]. The development of the universe is not known for sure until when and it will lead to what no one also knows. Scientists can only predict some theories of the destruction of the universe after the development of the universe reaches its maximum point. Theories of natural destruction are: big freeze, big rip, big crunch and big bounce. The four theories of destruction cannot be ascertained which is true because scientists can only guess from existing phenomena without any certainty related to the future of the universe or the process of the destruction of the universe.

The destruction of the universe is the destruction of the whole existing order or the shift of order or the balance of the universe to its disorder [10]. There are so many regularities in the universe, such as the movement of billions of stars and galaxies in the universe with separate orbits on their axes. However, sometimes there are collisions between celestial bodies that can cause chaos of the orderliness of the system of this universe. The more chaos occurs in nature, the closer the irregularities can cause the destruction of nature itself. The destruction of the universe will occur anywhere, both on earth and in the solar system, which will lead to universal destruction. The destruction of the universe originates from an imbalance of forces in the universe, in particular the force of gravity. After maximum development, the universe will begin to shrink and cause the force of gravity to increase as the volume of the universe is getting smaller or closer to zero. This gravitational pull causes the slow destruction of the universe, both on earth, in the sky and in all the natural order.

The destruction of the earth means the annihilation of all that is in it [11]. The end of the Earth is thought to be due to an enormous collision caused by the fall of some celestial bodies such as the giant meteor. The impact of the meteor will throw the Earth out of its orbit because centripetal force and centrifugal force are not balanced anymore. the centripetal force is the inward pull force released by the sun, and the centrifugal force is the outward pull force issued by the earth. The new Earth's orbit becomes a spiral trajectory, which continues to move closer to the Sun [12]. The end of the earth is also due to the contraction of the earth in all directions. The process of contraction of the Earth in all directions has been going on since the beginning. The very hot interior of the Earth gradually is less heat. When the stratosphere becomes small, re-adjustments should be made. This adjustment leads to changes in position and shape of the strata. 
This is the main cause of the height, pressure, folding and bending of the Earth's crust. This depreciation to some degree causes the explosion of volcanoes and earthquakes.

The destruction of the universe also occurs in the solar system. The sun, moon, stars, planets and other celestial bodies are just one of the solar systems among hundreds of billions of solar systems residing in the Milky Way galaxy. It is understood that the rotation of all objects in the sky is related to the gravitational pull of the galaxy. They spin to keep up so as not to fall on the galaxy. The galaxy will produce a centripetal force (inward tensile force), while the object in the sky emits centrifugal force. Both of these styles must be balanced, and should not be reduced or increased one of them. If there is an imbalance in the two forces, it will result universal destruction. Universal destruction is an event that makes all existing beings of the universe end, followed by the Day of Resurrection [13]. According to the latest scientific developments, almost all cosmologists agree with the opinion that the universe is mortal, the possibility in the past always arises and it later will disappear and will be replaced with something new. The origin of the universe which ranged from 10-15 billion years ago can be predicted by scientists. However, to predict the end of the universe is very difficult. This can only be seen by looking at the phenomenon as a sign around human life.

The various signs of destruction that arose before the destruction disregarded the universe. The sign of its destruction begins with the discovery of a supernova or a black hole in space. In the black hole the material and the constituents of the galaxy and the planet shrink so that the density becomes high. If matter and energy in the universe have exceeded their critical value, then the expansion of the universe will stop, because of the obstacles caused by the attraction of the energy mass. If the development stops, then the universe will contract. When this happens, then the galaxies will be docked again, the temperature and density of the cosmos material will become higher and eventually the entire universe disappears, including space, time and matter.

This galaxy's density is the opposite of the process of galaxy formation, whereby everything in the universe will be a single point with mass, zero volume and infinite density. This point is the point of nothingness when the universe is born. Based on the above illustration it can be concluded that the universe experiencing nothingness as opposed to its birth. This phenomenon is relevant to the big crunch nature destruction theory. Big crunch declared that the universe will continue to grow to the point of maximum, then after reaching the maximum point then the universe will experience compression or shrink and finally turn back into a point.

The destruction of the universe in Islam is identical with the apocalypse. Doomsday is the secret of God. No creature knows it including Prophet and His Apostle. Doomsday is the destruction of all that is in the world. All beings will die except what Allah Almighty wants. The balance that exists in the universe is not eternal, and it

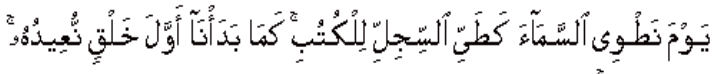

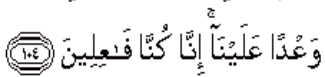
eventually makes the universe to the point of its destruction. There are several signs of destruction in the Qur'an, one of them as in

Al Anbiyaa'/21: 104 
Meaning: "(i.e,) on the day We rolled the heavens as rolled up the sheets of paper. As We have begun the first creation. Thus We will repeat it. That is a certain promise We keep; We are the ones who will do it." (Q.S. Al Anbiyaa'/21: 104)

The verse illustrates that one day the sky is rolled up easily as folded sheets of books or papers. The depiction of the heavens rolled up in this verse leads to an absence as this universe did not exist. The universe will return to its absence as it was at the birth of the universe. Signs of doomsday are also mentioned in the hadith of Bukhori no. 978:

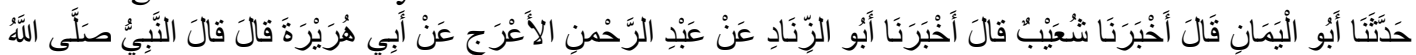

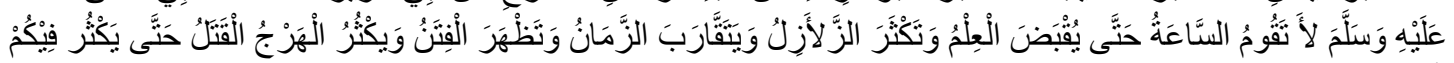

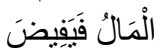

Meaning: Abu Al-Yaman has told us, Shu'aib has informed us, Abu Az Zinad from 'Abdurrahman Al A'raj from Abu Hurayrah has informed us he said that the Prophet sallallaahu' alaihi wasallam said that the Day of Resurrection will not accure except after the loss of knowledge, many earthquakes, time seems to run quickly, arising various slander, Al haraj-that is murder- and treasures abound to you. [14]

According to the theory of star evolution, the sun will enlarge into a red giant star ahead of his death. At that moment the sun shines so brightly, the ocean will boil and dry, the rock will melt, and life will be extinct. Then the sun will continue to grow until the planets around it into the ball of solar gas. This event is implied in Q.S. Al Qiyaamah/75: 7-9 as "the union of the sun and the moon". The total destruction begins with the contraction of the universe. Contraction or shrinking of the universe as described in the Qur'an about the day of the destruction of the universe. "When the sun is rolled up and when the stars fall" (Q.S. At Takwiir/81: 1-2). As the universe shrinks, the galaxies begin to close together and the stars collide each other to fall scatteredly on Earth. The universe diminishes in size, and eventually all matter in the universe will collapse back into a unity as it was at the beginning of its creation. This is called the big crunch as the opposite of the big bang, the big bang at the creation of the universe. This event is described by God in Q.S. Al Anbiyaa'/21: 104 by likening the contraction of the universe to the more incompressible sheets of rolled paper.

Several signs of the destruction of the universe (doomsday) that exist in the new hadith found by scientists, namely earthquakes around the world, the rising of the sun from the west, and fire emergence from Yemen. The earthquake throughout the world referred to in the hadith of Bukhari No.978 can be scientifically explained that the existence of the expansion of volcanic areas so that the volcanic area also extends through the cracks where at some point, there will be earthquakes and followed by erupting volcanoes.

The rise of the sun from the west can be scientifically explained that the process of shifting and friction arising from the tidal process, and blowing the wind towards the opposite direction of the rotation of the earth causes the speed of rotation of the earth is reduced and one day will force the earth to change the direction of rotation. In the end, the sun will rise from the direction of the drowning [15]. This phenomenon is consistent with the hadith narrated by Bukhari no.4270. The discovery of the 20th century proves that the area of volcanic eruptions spread along the western coast of the Arabian 
Peninsula, from Yemen to Syria. Half of this area is located in Hijaz. These volcanic flows have gone through a number of cracks in the earth's core and the volcano is still in active status. At one point the Hijaz will experience a phase of volcanic eruption that ejects lava from the crater and the gap until the entire city of Hijaz is full of fire and light [16]. This phenomenon has been mentioned in the hadith narrated by Bukhari no. 6585 .

The above fact is in harmony with the theory expressed by Rudolf Clausius concerning one of the laws of thermodynamics II known as total entropy. Total entropy is continuously increasing in the universe [17]. So the sun flows toward the cold part of the universe and this process cannot come back again. When the heat reaches a fixed temperature, it will arrive at a static state called thermodynamic equilibrium. The flow of heat from the sun and from billions of stars will increase for billions of years but it will not run out. At the end of a period of time, the laws of thermodynamics will make the activity in the universe finally stop. This event is according to the word of Allah in Q.S. At Takwiir: 1-2: "when the sun is rolled up, and when the stars fall" (Q.S. At Takwiir: 1-2). The purpose of the sun rolled in the verse is not yet known for certain. However, it can be interpreted that this rolled sun is dimming the sunlight, then goes out, and explodes, which can eventually become a black hole that has a very large gravity capable of pulling all the material near it, and nothing can escape from its bondage.

Many things that enable the destruction of all life on this earth starting from the meteor and asteroid blows, the mounting tsunami waves, storms and typhoons that blow terrible, lightning and thunder, volcanic eruptions that spewed hot lava, earthquakes and so forth.

Word of Allah means: "When the heavens are split, and when the stars fall apart, and when the oceans make overflow" (Q.S. Al Infithaar / 82: 1-3). In the word it contains a meaning of condition that is when the heavens have been split, and star stars falling to earth and sea water abundant land. When it happens, no one knows except Allah Almighty. Space experts around the world know that the earth is currently surrounded by thousands of meteors and asteroids of various sizes. Asteroids circulate around the earth and are held up by the earth's magnetic field until they do not fall to hit the earth. If the time of magnetic field that protects the earth becomes weak, all meteors and asteroids will fall upon the earth. This phenomenon is as intended in Q.S. Al Infithaar 82: 2 . The weak magnetic field that protects the earth is interpreted when the sky is split in Q.S. Al Infithaar/82: 1. In line with Q.S. Al Infithaar/82: 1-2, the Holy Prophet said in a hadith narrated by Imam Ahmad, namely: "The stars are the safeguards of the heavens. If the star dies, then it comes to the sky something that threatens it. "The purpose of the death of the star is the dimming and waning of the star. The intent of something threatening the sky is exposed, open, split, and unfashionable, abandoned, and filled with fog of smoke [18]. 
Stars are objects that have mass, large volumes, and high-temperature heat. In its life cycle, stars pass through several phases, namely: born, young, old, burst or dim, and extinguished. The star is a gigantic universal container oven that processes a series of nuclear reactions, called nuclear fusion processes that produce all the elements needed by earth and the sky. In addition to the gravitational forces that strongly bind the stars of the world to one another, there are also other forces that bind a material that is in the earth, and there in every celestial body, in the world sky sheets (until it does not fall and collide one another). Among its binding forces are strong nuclear power, weak nuclear power, and electric / magnetic (electromagnetic) power. These are the forces that bind and grasp the matter and energy present in the universe. The mass and magnetism of stars are so great that they are able to control all planets, satellites, comets, and all forms of matter in the orbits of the stars. The stars themselves bind each other with the gravitational force collected in one larger cosmic unit. They are related to each other by gravity as well. Therefore, if these gravitational bonds are released, the stars will fall, and the order of the universe breaks with the fall of the stars. In addition to the stars, also diungasa asteroids with varying sizes. Some small size asteroids will be burned by the earth's large atmosphere layers but the large ones will continue to hit the earth. If the fall lands, it will cause an explosion equivalent to thousands of atomic bombs, and if it falls at sea it will cause tsunami waves. This event is interpreted from verse as mentioned in Q.S. Al Infithaar/82: 3.

3.2 The Heisenberg Uncertainty Theory in the Destruction of the Universe

Quantum mechanics provides an important clue to the true destruction of the universe. One of the most basic and the most interesting ideas in quantum physics was proposed in 1927 by German physicist Werner Heisenberg on the principle of uncertainty. He stated that it can be never simultaneously to determine the exact position and momentum of a particle. Heisenberg stated that this cannot be done, even theoretically, because the notion of position and velocity is virtually meaningless in nature [19].

One simple illustration is if we try to determine the exact position of an electron. These particles are so small that they can only be detected with something that has quite small wavelengths, such as gamma rays. But when these gamma rays hit an electron, it also affects momentum in an unpredictable way. So it is impossible to determine the position of an electron without changing its momentum. And if we try to determine it more precisely (by using shorter waves), then the greater effect on the momentum of the electron will appear. Likewise, if the momentum is not much affected, then our assessment of the position of the electron is also less precise. As with particle, it is also applied to the field. Heisenberg's uncertainty principle provides amazing results when applied to space.

The principle of Heisenberg's uncertainty provides a clue to the real destruction of the universe. Where, the space of the universe has pairs of virtual particles (particles and anti-particles). Before the particles and their antiparticles cancel each other out, they are exposed to semen influences. Negative particles are withdrawn and positive ones are rejected. They then turned into radiation so that the black hole emits thermal radiation (heat) that can measure temperature. These virtual particle pairs are constantly moving 
in and out, mutually shaping and negating each other. This results above and less than zero in the emergence of movement slightly. This behavior occurs during the evolution of stars, and so long as the principle of Heisenberg's uncertainty.

The principle of Heisenberg's uncertainty in the destruction of the universe in particular is seen from the point of view of the dimension of time space in the moment after matter. The rule is drawn into the horizon event and into the singularity, which is the place where the classical concepts of space and time collapse. In this area, events that occur with the material cannot be known with certainty as to whether the material will be drawn again until the trough of the black hole itself due to its high gravity, or it will move slightly above the black hole trough, or it even just moves a bit of the singularity. In fact, the nature of the existing and applicable laws in the material cannot be known with certainty.

\section{Conclusions}

The destruction of the universe in Q.S. Al Infithaar: 1-3 is understood that the destruction of the universe is depicted when the sky is split, the stars fall, and the sea is swept away. The sky splitting in this case is interpreted as the destruction of the order of the universe which then the stars fall scatteredly because of the gravitational force that keeps it lost. Not only stars fall, but also the objects in the sky, including asteroids of the same size are scattered. Some small sized asteroids will be burned by the earth's large atmosphere layers but the large one will continue to hit the earth. If the falling material lands, it will cause an explosion equivalent to thousands of atomic bombs, and if it falls at sea, it will cause tsunami waves. Ultimately the size of the tomic suba, which is in accordance with the uncertainty principle of heisenberg, is evasive to be known because the nature of the subatomic particle itself is not due to human limitations, nor tools.

\section{References}

[1] Ridwan Abdullah Sani, Sains Berbasis Al Qur'an (Jakarta: Bumi Aksara, 2014), hal. 221.

[2] Misbach Munir, Misteri Keajaiban Surat Al Fatihah (Indonesia: Agung Media Mulia, t.th.), hal. 106.

[3] Siti Marwiyah, “Kembali Kepada Ketiadaan” Al Kisah, no. 08 (20 April - 3 Mei 2009), hal. 13.

[4] Lajnah Pentasih Al Qur'an Departemen Agama RI, Al Qur'an dan Terjemahannya (Bandung: Syaamil Cipta Media, 2005), hal. 587.

[5] Sri Jumini, "Teori ketidakpastian Heisenberg dalam Peristiwa Isro' Mi'roj". Prosiding Seminar Nasional Pendidikan Sains 2016. Universitas Sebelas Maret Surakarta. Hal. 469.

[6] Mestika Zed, Metode Penelitian Kepustakaan (Jakarta: Yayasan Obor Indonesia, 2008), hal. 2.

[7] Abdul Mustaqim, Metode Penelitian Al Qur'an dan Tafsir (Yogyakarta: Idea 
Press, 2014), hal. 18.

[8] Feris Firdaus, Alam Semesta:Sumber Ilmu, Hukum, dan Informasi Ketiga setelah Al Qur'an dan Al Sunnah (Yogyakarta: Insania Cita Press, 2004), hal. 74.

[9] Feris Firdaus, Alam Semesta:Sumber Ilmu, Hukum, dan Informasi Ketiga setelah Al Qur'an dan Al Sunnah (Yogyakarta: Insania Cita Press, 2004), hal. 68.

[10] Feris Firdaus, Alam Semesta:Sumber Ilmu, Hukum, dan Informasi Ketiga setelah Al Qur'an dan Al Sunnah (Yogyakarta: Insania Cita Press, 2004), hal. 78.

[11] Bakker, Anton. 1995. Kosmologi dan Ekologi. Yogyakarta: Kanisius. Hal. 427

[12] Arifin. 1997. Agama, Ilmu, dan Teknologi. Jakarta: Golden Terayon Press. Hal. 93

[13] Hawking, Stephen W. 2004. Teori Segala Sesuatu: Asal-usul dan Kepunahan Alam Semesta. Yogyakarta: Pustaka Pelajar. Hal. 46

[14] Ibnu Majjah Abu Salsabila, Kitab Shahih Bukhori www.ibnumajjah.com hadis no. 978 (13 Maret 2017)

[15] Zaghlul An Najjar, Sains dalam Hadis Mengungkap Fakta Ilmiah dari Kemukjizatan Hadis Nabi (Jakarta: Bumi Aksara, 2011), hal. 108.

[16] Zaghlul An Najjar, Sains dalam Hadis Mengungkap Fakta Ilmiah dari Kemukjizatan Hadis Nabi (Jakarta: Bumi Aksara, 2011), hal. 103.

[17] Caner Taslaman, The Miracle of Al Qur'an, Keajaiban Al Qur'an Mengungkap penemuan-penemuan Ilmiah Modern (Bandung:Mizan, t.th.), hal. 281.

[18] Zaghlul An Najjar, Sains dalam Hadis Mengungkap Fakta Ilmiah dari Kemukjizatan Hadis Nabi (Jakarta: Amzah, 2011), hal. 3.

[19] Rizka, "Adakah Hukum Fisika yang Berlaku di Black Hole" https://rizknareedh.wordpress.com/2012/03/17/adakah-hukum-fisika-yangberlaku-di-black-hole/, (28 April 2017) 